\title{
Processing fish press waters using metallic and ceramic filtration
}

\author{
Raúl Pérez-Gálvez ${ }^{1,{ }^{*}}$, Emilia M. Guadix ${ }^{1}$, Jean-Pascal Bergé ${ }^{2}$, Antonio Guadix $^{1}$ \\ ${ }^{1}$ Departamento de Ingeniería Química, Universidad de Granada, Granada, Spain \\ 2 Laboratoire Science et Technologie de la Biomasse Marine, IFREMER, Nantes, France \\ *: Corresponding author : Raúl Pérez-Gálvez, email address : rperezga@ugr.es
}

\begin{abstract}
:
BACKGROUND

The press juices resulting from a compacting operation on fish by-products were subjected to a depuration treatment in order to reduce the high COD $(120 \mathrm{~g} \mathrm{O} 2 \mathrm{~L}-1)$. The process included an initial de-particulation step by means of two metallic filter cartridges of $465 \mu \mathrm{m}$ and $250 \mu \mathrm{m}$, followed by concentration with a $200 \mathrm{~nm}$ ultrafiltration ceramic membrane. The polishing efficiency of each unit was assessed in terms of COD and protein removal.
\end{abstract}

\section{RESULTS}

Dead-end metallic filtration of the press waters reduced their suspended matter content by $28 \%$, but achieved only $5.6 \%$ decrease in chemical oxygen demand (COD), which suggested further processing by membrane ultrafiltration. The de-particulated stream was then subjected to ultrafiltration for $8 \mathrm{~h}$ in batch concentration mode, attaining a COD reduction of $87 \%$. The observed flux of permeate was successfully fitted to a cake-forming model adapted to cross-flow filtration. The permeability of the fouled membrane was completely restored $(99.87 \%)$ by a cleaning treatment comprising an alkali step with $\mathrm{NaOH}$ and a final disinfection with $\mathrm{NaOCl}$.

\section{CONCLUSIONS}

The treatment proposed has proved to be a feasible technology, able to render a final permeate with reduced organic load. (c) 2013 Society of Chemical Industry

Keywords : membranes ; waste-water ; bioseparations ; filtration

\section{Introduction}

Compacting procedures are widely employed in the processing of fish materials. On board fishing vessels compaction of fish discards or fish processing waste is necessary in order to reduce the volume of biomaterials to be stored.[1, 2] This operation leads to less space requirements and refrigeration loads for insulation of the cold store.[3] In the field of waste management previous dewatering operation of wastes or by-products facilitates their handling, since a reduction in the moisture content implies lower transport and processing costs. $[4,5]$

The compaction of fish materials generates a press cake, which is normally reduced to fish meal intended for aquaculture[6,7] and press waters having high levels of organic matter which cannot be 
directly discharged without a suitable depuration treatment. As other end-pipe effluents, the depuration treatment of the press juices must start by a conventional filtration stage in order to remove the suspended solids from the effluent. Filter devices based on dead-end filtration are not able to remove particles below $10 \mu \mathrm{m}$, so their polishing efficiency, in terms of $\mathrm{COD}$ or $\mathrm{DBO}_{5}$ removal, is limited $^{8}$. To this regard, membrane-based separation technologies are increasingly being implemented in effluent treatment processes since they are able to remove most of the organic compounds present in the effluent stream without involving the use of chemicals or energy separating agents. In the field of fish processing wastewaters, membrane technologies are available for depuration treatments intended to reduce the organic load of polluted effluents or process waters ${ }^{9-10}$. Furthermore, membrane separation technologies have been widely employed to recover valuable molecules, such as lipids or proteins of interest in the formulation of animal or human feedstuffs. ${ }^{11-12}$

One of the major constraints to a further utilization of membrane technologies is the irreversible decrease of the membrane permeability due to the deposition or accumulation of particles on the membrane surface, and/or the precipitation of smaller solutes on the surface or within the pores, which is referred to as fouling. ${ }^{13-15}$ The permeate flux through a fouled membrane cannot be restored without a suitable cleaning process, including an initial rinse with water, one or more cleaning steps employing chemical agents and eventually disinfectants. ${ }^{16}$

The first empirical models relating the flux decay with the fouling mechanisms were developed by Hermia ${ }^{17}$ for dead-end filtration. In order to extent the Hermia models to cross-flow systems, it is necessary to account for the interactions between the bulk solution and the particles deposited on the foulant layer. For instance, the Suki's model ${ }^{18}$ assumes that the flux decay during ultrafiltration is caused by the formation of a cake of rejected material on the membrane surface, whose growth is limited by the dragging force of the retentate stream, which acts perpendicularly to the mass deposition. This approach was employed in this work to model the evolution of the flux of permeate throughout 8 hours of concentration.

The aim of this paper is to study the efficiency of a two-step depuration treatment of the press juices resulting from a compacting operation of sardine by-products. The operation proposed comprised an 
initial dead-end filtration by means of two in-series metallic filter cartridges, followed by a batch concentration with a $200 \mathrm{~nm}$ ultrafiltration ceramic membrane. The polishing efficiency of each unit was assessed in terms of COD, particles and protein removal. In order to obtain a predictive model for the concentration process, the flux of permeate throughout the ultrafiltration was fitted to a Suki's model. Finally, a two-step cleaning protocol comprising an alkali cleaning and a final disinfection was assayed to restore the initial permeability of the membrane.

\section{EXPERIMENTAL}

\section{Fish compaction procedure}

Sardine by-products were provided by the fish canning company Saupiquet, located in Quimper (France). They were kept in ice during the transport and pressed the same day to minimise the spoilage of the raw material. The raw material presented a proximate composition as follows: Water $62 \%$, protein $16 \%$ and lipids $17 \%$, ash $3 \%$.

The compaction of the sardine by-products was accomplished batchwise, by means of a pilot prototype able to treat up to 10 kilograms of fish per batch. This prototype comprised a grinding unit

attached to a hydraulic press by means of a belt conveyor. The sardine by-products were fed into the cutting machine provided with a rotary cutter with four circular blades. The grinded material was received inside a parallelepiped-shaped steel mould and conveyed into the hydraulic press, where it was subjected to the compaction treatment comprising 3 consecutive pressing steps where the raw material was subjected to a maximum pressure of $150 \mathrm{bar}$.

The juice released by this operation was collected inside a storage tank placed under the hydraulic press. The remaining cake was received in a tray and kept in the cold store.

\section{Biochemical characterisation of the raw and filtered press juices}

The moisture and ash content of the raw and filtered juices were determined gravimetrically according to the official methods recognised by the Association of the Official Analytical Chemists. ${ }^{19}$ The content of protein in press cake, press waters and the concentrate was determined by the Kjeldahl 
method, employing a conversion factor of 6.25 (equivalent to 0.16 grams of nitrogen per gram of protein), which is commonly used in food applications ${ }^{20}$.With regard to the content of lipids, they were extracted from the sample according to the method described by Folch et al. ${ }^{21}$

The concentration of soluble protein in the permeate samples was very low to be precisely determined by the standard Kjeldahl method. The Bicinchonicic Acid (BCA) Method ${ }^{22}$ was used instead, employing a spectrophotometer microplate reader (Anthos Labtec HT3, Austria). The Chemical Oxygen Demand (COD) of the raw and filtered juices were determined according to the Open Reflux Method $^{23}$, which employs dichromate as oxidant agent.

\section{Metallic dead-end filtration}

The metallic dead-end filtration step employed two stainless-steel Dynamesh filter cartridges (Pall, USA) of $465 \mu \mathrm{m}$ and $250 \mu \mathrm{m}$ rating size, each one providing a filtration area of $0.1022 \mathrm{~m}^{2}$. Each filter cartridge is placed inside a housing which provides a hold-up volume of 2.75L.

The press waters recovered from the compaction treatment were firstly pumped through the $465 \mu \mathrm{m}$ filter cartridge, received into an intermediate tank and then passed through the second cartridge of 250 $\mu \mathrm{m}$ rating size. The pressure drop through each filter element was monitored by means of two by inline PN2026 manometers (IFM Electronic, Germany), placed at the inlet and outlet of each cartridge. The permeability of both filter elements was determined by measuring the pressure drop caused by the passage of water or press liquor at variable volumetric flow. The pressure drop through the filter elements should be kept below a maximum value of tolerance, above which the filter cartridge should be replaced and cleaned. Following technical recommendations, the volumetric flow was varied within the range $5-10 \mathrm{~L} / \mathrm{min}$ to limit the exhausting of the filter media.

Finally, samples of the initial prefiltered press liquor and the filtered streams exiting the $465 \mu \mathrm{m}$ and the $250 \mu \mathrm{m}$ were obtained for determination of their content in suspended particles and COD, as well as their proximate composition. The content of suspended solids was determined for the feed solution and the $465 \mu \mathrm{m}$ and $250 \mu \mathrm{m}$ filtered streams. It was reported as the wet weight of the solid residue obtained after centrifugation at $10000 \times \mathrm{g}$ and $15 \mathrm{~min}$, related to the mass of liquid. 


\section{Ceramic tangential ultrafiltration}

The ultrafiltration assay was undertaken by means of a Maxim pilot ultrafiltration system (Pall, USA) equipped with a 10-L feed tank containing the prefiltered press liquor, whose temperature was kept constant at $20^{\circ} \mathrm{C}$ by means of a cooling coil with glycol as refrigerant. The press waters were pumped through an UF module containing a mono-channel ET1-070 Membralox ceramic membrane (Pall, USA) of $7 \mathrm{~mm}$ diameter and $250 \mathrm{~mm}$ length. The active layer of zirconite $\left(\mathrm{ZnO}_{2}\right)$ provided an overall filtration surface of $0.005 \mathrm{~m}^{2}$, with an average pore size of $200 \mathrm{~nm}$. Membrane pore size and operating parameters (i.e. transmembrane pressure, cross-flow velocity) were selected according to the results obtained in a previous work ${ }^{24}$.

The pre-filtered juice was concentrated for $8 \mathrm{~h}$ at constant cross-flow velocity $(3.3 \mathrm{~m} / \mathrm{s})$ and transmembrane pressure (1.5 bar). The batch filtration mode was chosen for this operation, with recirculation of the retentate to the feed tank while the permeate stream was continuously removed. The flux of permeate was determined throughout the batch concentration operation. Besides this, seven samples of permeate and retentate were collected after 30 minutes, 1, 2, 3, 4, 6 and $8 \mathrm{~h}$ of operation, in order to monitor the COD of the permeate and the concentration of protein in both the retentate and the permeate streams.

A cleaning treatment, involving an alkali and a disinfection stage, was applied to restore the initial water flux of the membrane after the concentration. The complete cleaning sequence comprised the following steps:

- Initial rinse of the fouled membrane with demineralised water at $20^{\circ} \mathrm{C}$ and cross-flow velocity $3.3 \mathrm{~m} / \mathrm{s}$. Firstly, the retentate port was drained with the retentate valve fully open, and then the membrane was rinsed at 1.5 bar with recycle of both the retentate and the permeate streams.

- Alkaline treatment with a solution containing $20 \mathrm{~g} / \mathrm{L} \mathrm{NaOH}$ plus $2 \mathrm{~g} / \mathrm{L}$ of sodium dodecyl sulphate (SDS) at $50^{\circ} \mathrm{C}$. Total recirculation mode for 30 minutes at a cross-flow velocity of $3.3 \mathrm{~m} / \mathrm{s}$ and 1.5 bar of transmembrane pressure. 
- Disinfection stage with a $\mathrm{NaClO}$ solution $\left(250 \mathrm{ppm}_{2}\right.$ ) plus $0.5 \mathrm{~g} / \mathrm{L} \mathrm{NaOH}$ to prevent the corrosion of the steel elements and piping. ${ }^{25}$ Temperature was set at $30^{\circ} \mathrm{C}$, transmembrane pressure was 1.5 bar and the cross-flow velocity was $3.3 \mathrm{~m} / \mathrm{s}$. The total recirculation mode was followed for $15 \mathrm{~min}$.

After completing each stage, both ports were rinsed with demineralised water until neutrality of the permeate and the retentate streams. At this point, the water flux was determined again to evaluate the recovery of the membrane permeability throughout the cleaning procedure.

\section{RESULTS AND DISCUSSION}

\section{Metallic dead-end filtration}

The pressure drop $(\Delta \mathrm{P})$ through a horizontal filter element will be proportional to the square of the volumetric flow passing through the element, according to Eq. (1):

$$
\Delta P=k \cdot Q^{2}
$$

The water pressure drop through both filter cartridges was determined by measuring the pressure drop at a variable flow of demineralised water, as shown in Fig. 2a. This figure shows a good correlation between the pressure drop and the square of the volumetric flow, as reflected by the coefficients of determination $\mathrm{R}^{2}=0.9862$ for the $465 \mu \mathrm{m}$ filter cartridge and $\mathrm{R}^{2}=0.9860$ for that of $250 \mu \mathrm{m}$ rating size. The higher the slope of the regression line $(\mathrm{k})$ is, the larger is the hydraulic resistance provided by the filter cartridge. Indeed, the slope for the $465 \mu \mathrm{m}$ filter was $\mathrm{k}=3.610^{-3} \mathrm{bar} \cdot \mathrm{min}^{2} / \mathrm{L}^{2}$, compared to $\mathrm{k}=$ $4.1 \cdot 10^{-3} \mathrm{bar} \cdot \mathrm{min}^{2} / \mathrm{L}^{2}$ for the filter cartridge of smaller rating size.

A similar test was performed on the press waters, as shown in Fig. 2b. In this case, the solid particles were retained on the filter surface and within the filter medium, reducing the effective filtration area and increasing the hydraulic resistance to the fluid passage. Fig. 2b shows the regression lines for the press waters, whose coefficients of determination were $R^{2}=0.9794$ and $R^{2}=0.9957$ for the $465 \mu \mathrm{m}$ and $250 \mu \mathrm{m}$ filter cartridge, respectively. The hydraulic resistance $(\mathrm{k})$ for the filter of $465 \mu \mathrm{m}\left(4.1 \cdot 10^{-}\right.$ 
${ }^{3}$ bar $\cdot \mathrm{min}^{2} / \mathrm{L}^{2}$ ) was similar to that obtained for water, while the slope for the $250 \mu \mathrm{m}$ filter increased up to $4.6 \cdot 10^{-3} \mathrm{bar} \cdot \mathrm{min}^{2} / \mathrm{L}^{2}$.

According to the results shown in Fig. 3, the overall filtration treatment removed more than $28 \%$ of the mass of suspended particles present in the feed solution. The second cartridge was clearly more effective than the first one, owing to its lower rating size. Nevertheless, the first filtration stage is necessary, in order to prevent larger particles to exhaust the filter medium.

Similarly, the contaminant holding capacity was evaluated for each cartridge by means of its COD removal. The average COD of raw the press juice was $120 \mathrm{~g} \mathrm{O}_{2} / \mathrm{L}$. This value is similar to that estimated by Guerrero et al. ${ }^{26}$ for the range of COD of the effluents resulting from a fish meal plant (30-120 $\mathrm{g} \mathrm{O}_{2} / \mathrm{L}$ ). The overall filtration pre-treatment only achieved 5.6\% decrease in the COD of the effluent, which indicates that most of the oxidisable species are present under the form of soluble compounds, which were not retained by the filter cartridges.

The suspended particles present in the press liquor are originated from the flesh tissue disruption during the pressing treatment, and therefore are mostly made up of proteins. This assumption was evidenced by the protein content of the raw and filtered liquor, shown in Fig. 3, which indicates that the content of proteins decreased from $7.23 \% \mathrm{w} / \mathrm{w}$ to $4.41 \% \mathrm{w} / \mathrm{w}$ after the complete filtration treatment. From these results it can be calculated an overall $42.7 \%$ protein removal for the whole filtration treatment, mostly attributed to the $250 \mu \mathrm{m}$ filtration stage (33.3\%).

Although the particulate and protein removal attained after the filtration treatment were significant, the low values of COD removal suggested employing a subsequent membrane separation operation in order to reduce the content of dissolved matter in the final effluent prior to its discharge.

Ceramic tangential ultrafiltration

\section{Evolution of the permeate flux during the batch concentration}

Two litres of feed solution were concentrated for $8 \mathrm{~h}$, with recycle of the retentate stream to the feed tank while the permeate was collected in a separate recipient. The total volume of permeate collected 
after the concentration experiment was $831 \mathrm{~mL}$, which represents a volume reduction factor (VRF) of 1.7 .

The flux of permeate was measured throughout the concentration operation, as shown in Fig. 4. The experimental data show a continuous decline of the flux of permeate in time and were fitted to the Suki's model, as represented by the solid line in Fig. 4. This approach is based on the resistances-inseries model, in which the fouling resistance is assumed to be proportional to the amount of matter deposited on the membrane, which increases with time according to a first-order kinetics until reaching a value of equilibrium where the deposition of foulants is balanced by the tangential migration of particles dragged by the retentate flow. The flux of permeate $\mathrm{J}$ decreases in time according to the Eq. (2):

$$
J=\frac{J_{0}}{1+\left(\frac{J_{0}}{J_{\infty}}-1\right) \cdot(1-\exp (-k \cdot t))}
$$

while $\mathrm{J}_{0}$ stands for the initial flux, $\mathrm{J}_{\infty}$ is an asymptotic value of flux which is attained when the time of operation tends to infinity, and $\mathrm{k}$ is the first-order constant. The observed flux was fitted to the Suki's model by non-linear regression, obtaining a coefficient of determination $\mathrm{R}^{2}=0.9676$. This model predicts an initial permeate flux $\mathrm{J}_{0}=27.6 \mathrm{~L} /\left(\mathrm{m}^{2} \cdot \mathrm{h}\right)$, which is slightly inferior to that observed ( $\approx 29$ $\left.\mathrm{L} /\left(\mathrm{m}^{2} \cdot \mathrm{h}\right)\right)$, with an initial steep decline followed by a stabilisation zone where the permeate flux falls at decreasing rate until attaining a steady value $\mathrm{J}_{\infty}=18.9 \mathrm{~L} /\left(\mathrm{m}^{2} \cdot \mathrm{h}\right)$. In our case, the permeate flux decreased continuously in time without attaining a steady value at the end of the concentration. As the protein content of the feed solution increases in time, and so the convective mass transport from the bulk solution to the membrane, the cake layer can grow to a larger extent without attaining a stable value within the $8 \mathrm{~h}$.

\section{Protein rejection and $C O D$ of the permeate}

Seven samples of permeate and retentate were collected after 30 minutes, 1, 2, 3, 4, 6 and 8 hours of operation, in order to monitor the protein content in both the retentate and the permeate, as well as the COD of the permeate stream. Fig. 5 represents the time evolution of both variables for the permeate 
stream. The protein content in the permeate (denoted as $c_{P}$ ) increased slightly within the first hour from an initial value of $8.2 \mathrm{mg} / \mathrm{mL}$ to $8.4 \mathrm{mg} / \mathrm{mL}$, followed by a plateau with a steady value of protein content around $8.3 \mathrm{mg} / \mathrm{mL}$ and then decreased down to $7.8 \mathrm{mg} / \mathrm{mL}$ at the end of the concentration operation. Considering that the protein content of the retentate $\left(C_{R}\right)$ increased in the course of the concentration from $44 \mathrm{mg} / \mathrm{mL}$ to $73.6 \mathrm{mg} / \mathrm{mL}$, the percentage of protein rejection (PR), which was evaluated by Eq. (3), remained constant in time with an average value of 88\%:

$$
P R(\%)=\left(1-\frac{C_{P}}{C_{R}}\right) \times 100
$$

This behaviour is in accordance to the proposed model for the permeate flux, where the fouling resistance increases in time until attaining a limiting value. This final resistance remains constant in time and controls the transmission of proteins through the cake layer.

Similarly, the COD of the permeate stream experienced a rapid decline within the first hour and then it did not vary significantly in the course of the concentration, presenting an average value of $15.5 \mathrm{~g}$ $\mathrm{O}_{2} / \mathrm{L}$. The COD removal efficiency (CODR) was calculated by the Eq. (4):

$$
\operatorname{CODR}(\%)=\left(1-\frac{C O D_{P}}{C O D_{0}}\right) \times 100
$$

where $\mathrm{COD}_{\mathrm{P}}$ is the COD of the permeate stream at a given time and $\mathrm{COD}_{0}$ is a value of reference, in our case the COD of the raw press liquor prior to the depuration treatment. An average COD removal efficiency of $86 \%$ was obtained by the membrane concentration operation, considering the initial COD of the pre-filtered press waters $\left(118 \mathrm{~g} \mathrm{O}_{2} / \mathrm{L}\right)$. The COD removal for the overall depuration treatment (filter cartridges + batch concentration) was 87\%, related to the COD of the raw press waters $\left(125 \mathrm{~g} \mathrm{O}_{2} / \mathrm{L}\right)$.

\section{Cleaning treatment}

After the completion of the batch concentration, the membrane was cleaned following a cleaning sequence comprising an alkali stage with $\mathrm{NaOH}$ to hydrolyse and remove the protein aggregates deposited on the membrane surface, followed by a final disinfection with $\mathrm{NaOCl}$. The membrane was 
rinsed with demineralized water after each cleaning step, and then its water flux was measured. The recovery of the water flux throughout the cleaning procedure was shown in Fig. 6, where the water flux was fitted to the transmembrane pressure (TMP) by a straight line. As shown in this figure, the slope of the regression lines (i.e. the water permeability) is minimal after completing the concentration, and then increases throughout the cleaning stages until coinciding with the dotted line, which represents the permeability of the unfouled membrane. Similarly, the cleaning efficiency obtained by each cleaning stage was evaluated by the evolution of the total hydraulic resistance $\left(\mathrm{R}_{\mathrm{T}}\right)$ and the resistance of the fouling layer $\left(\mathrm{R}_{\mathrm{F}}\right)$, which permitted to evaluate a cleaning efficiency index (E) for each cleaning stage. The total hydraulic resistance $\left(R_{T}\right)$ provided by the membranes after each cleaning step was determined as the inverse of its water permeability, while the resistance provided by the fouling deposits $\left(\mathrm{R}_{\mathrm{F}}\right)$ was evaluated by Eq. (5):

$$
R_{F}=R_{T}-R_{M}
$$

The cleaning efficiency index was defined as the percentage water flux recovery provided by a given cleaning stage related to the total water flux recovery attained by the complete cleaning procedure. This index could be evaluated for each cleaning stage as a function of the hydraulic resistances, according to Eq. (6) and Eq. (7):

$$
\begin{gathered}
E_{\mathrm{NaOH}}=\frac{R_{0}-R_{\mathrm{NaOH}}}{R_{0}-R_{M}} \times 100 \\
E_{\mathrm{NaOH}}=\frac{R_{\mathrm{NaOH}}-R_{\mathrm{NaOCl}}}{R_{0}-R_{M}} \times 100
\end{gathered}
$$

where $R_{M}$ represents the intrinsic membrane resistance (i.e. evaluated for the clean membrane before the ultrafiltration), $\mathrm{R}_{0}$ is the resistance of the fouled membrane (after 8 hours of ultrafiltration), and the intermediate resistances $\mathrm{R}_{\mathrm{NaOH}}$ and $\mathrm{R}_{\mathrm{NaOCl}}$ were determined after the alkali and disinfection stage, respectively. Similarly, a total cleaning efficiency index, which accounts for the global restore of the membrane permeability after completing the cleaning procedure, was defined as the sum of both individual cleaning indices, according to Eq. (8): 


$$
E_{\text {Total }}=E_{\mathrm{NaOH}}+E_{\mathrm{NaOCl}}
$$

The total and fouling resistances, as well as the efficiency indices throughout the cleaning procedure were are summarised in Table 1. It can be noticed than the chosen 2-stage protocol was able to restore completely the initial water permeability of the membrane, with an overall cleaning efficiency $99.87 \%$ and a residual resistance (i.e. difference between the resistances $R_{N a O C l}$ and $R_{M}$ ) which represented $0.66 \%$ of the intrinsic membrane resistance. According to Argüello et al..$^{27}$, the membrane is assumed to be completely clean if this percentage is lower than $0.70 \%$.

It should be stressed that the alkali stage itself was responsible for $83 \%$ of the total fouling removal. According to Bartlett et al. $^{28}$ the high cleaning efficiency of alkali solutions was attributed to their ability to hydrolysate and to dissolve the protein deposits. Regarding the disinfection stage with sodium hypochlorite, it was effective to restore the initial water flux of the membrane. As reported in previous literature ${ }^{29}, \mathrm{NaOCl}$ is able to inhibit microbial proliferation, due to the release of free chlorine $\left(\mathrm{Cl}_{2}\right)$, as well as to remove the organic material deposited on the membrane surface and within the pores. This fact is owed to the oxidation of organic compounds to other groups, such as aldehydes, ketones or carboxylic acids, which exhibit higher hydrophilicity and thus, a lower adhesion to the membrane material.

\section{CONCLUSIONS}

The treatment proposed in this work (metallic filtration followed by ceramic ultrafiltration) has proved to be a feasible technology able to render a final permeate with a reduced organic load. The metallic filtration step was able to remove $28 \%$ of the suspended matter, while the reduction of the COD was only $5.6 \%$, suggesting the need of a subsequent ultrafiltration operation. To this purpose, a batch concentration was performed with a $200 \mathrm{~nm}$ ultrafiltration ceramic membrane. After $8 \mathrm{~h}$ of operation, the feed volume was concentrated in a VRF $=1.7$ and the permeate flux dropt to a stable value around $19 \mathrm{~L} /\left(\mathrm{m}^{2} \cdot \mathrm{h}\right)$. The time evolution of the permeate flux was successfully fitted to a cakeforming model adapted to the cross-flow filtration ${ }^{18}$. In global terms, the treatment proposed was able to remove up to $87 \%$ of the effluent COD. In order to restore the initial permeability of the membrane 
after the treatment, a cleaning protocol comprising an alkali step with $\mathrm{NaOH}$ and a final disinfection with $\mathrm{NaOCl}$ was successfully assayed.

\section{ACKNOWLEDGEMENTS}

This work was funded by the projects LIFE 05/ENV/000267 from the UE LIFE Programme and CTQ2008-02978, CTQ2011-23009 from the Spanish Ministry of Science and Innovation.

\section{REFERENCES}

1. FAO, Code of conduct for responsible fisheries. FAO Fisheries Department, Rome (1995).

2. Pérez-Gálvez R, Chopin C, Ragon JY, Guadix A and Bergé JP, Optimization of the liquor yield during the hydraulic pressing of sardine (Sardina pilchardus) discards. J. Food Eng. 93: 6671 (2009).

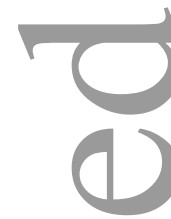

3. Johnston WA, Nicholson FJ, Roger A and Stroud GD, Freezing and refrigerated storage in fisheries. FAO Fisheries Department, Rome (1994).

4. García AJ, Esteban MB, Márquez MC and Ramos P, Biodegradable municipal solid waste: characterization and potential use as animal feedstuffs. Waste Manage. 25:780-787 (2005).

5. Ghiasinejad $\mathrm{H}$ and Abduli S, Technical and economical selection of optimum transfer-transport method in solid waste management in metropolitan cities. Int. J. Environ. Res. 1: 179187(2007).

6. Bimbo AP, Production of fish oil, in Fish oils in nutrition, ed by Stansby ME. Reinhold Publishing, New York, pp 141-180 (1990).

7. Ruiter A, Fish and fishery products composition, nutritive properties and stability, in Fish meal and fish oil- not only by-products, ed. by Schmidtdorff W. Biddles Limited, London, pp 347-376 (1995). 
8. Cheremisinoff NP, Cartridge and other filters worth mentioning, in Handbook of water and wastewater treatment technologies, ed. by Cheremisinoff NP. Butterworth-Heinemann, Woburn, pp. 224-234 (2002).

9. Mameri N, Abdessemed D, Belhocine D, Lounici H, Gavach C, Sandeaux C, and Sandeaux R, Treatment of fishery washing water by ultrafiltration. J. Chem. Technol. Biotechnol. 67: 169175 (1996).

10. Massé A, Vandanjon L, Jaouen P, Dumay J, Kéchaou E, and Bourseau P, Upgrading and pollution reduction of fish industry process-waters by membrane technology, in Added Value to Fishery Wastes, ed. by Bergé JP. Transworld Research Network, Kerala, pp 81-100 (2008).

11. Shackleton, R. The application of ceramic membranes to the biological industries. J. Chem. Technol. Biotechnol. 37: 67-69 (1987).

12. Thomson AR, Recent Developments in Protein Recovery and Purification. J. Chem. Technol. Biotechnol. 34 :190-198(1984).

13. Zydney AL, Membrane fouling, in Microfiltration and ultrafiltration: principles and applications, ed. by Zeman LJ and Zydney AL. Marcel Dekker Inc., New York, pp 397-446 (1996).

14. Aouni A, Fersi C, Cuartas-Uribe B, Bes-Piá A, Alcaina-Miranda MI and Dhahbi M, Study of membrane fouling using synthetic model solutions in UF and NF processes. Chem. Eng. J. 175 : 192-200 (2011).

15. Wang Q, Wang Z, Wu Z, Ma J and Jiang Z, Insights into membrane fouling of submerged membrane bioreactors by characterizing different fouling layers formed on membrane surfaces. Chem. Eng. J. 179: 169-177(2012).

16. Trägårdh G, Membrane cleaning. Desalination 71: 325-335 (1989).

17. Hermia J, Constant pressure blocking filtration laws: Application to power-law non-Newtonian fluids. Trans. Ind. Chem. Eng. 60: 183-187 (1982). 
18. Suki A, Fane AG and Fell JD, Flux decline in protein ultrafiltration. J. Membr. Sci. 21 : 269-283 (1984).

19. AOAC, Official Methods of Analysis of AOAC International, AOAC International, Gaithersburg (2006).

20. Adler-Nissen J, Enzymic hydrolysis of food proteins. Elsevier Applied Science Publishers LTD, London (1986).

21. Folch J, Lees M and Sloan-Standley GH, A simple method for the isolation and purification of total lipids from animal tissues. J. Biol. Chem. 226:497-509 (1957).

22. Smith PK, Krohn RI, Hermanson GT, Mallia AK, Gartner FH, Provenzano MD, Fujimoto EK, Goeke NM, Olson BJ and Klenk DC, Measurement of protein using Bicinchoninic Acid. Anal. Biochem. 150 : 76-85 (1985).

23. Clescerl LS, Greenberg AE, Eaton AD, Standard Methods for Examination of Water \& Wastewater. American Public Health Association, Washington (2005).

24. Pérez-Gálvez R, Guadix EM, Bergé JP, Guadix A, Operation and cleaning of ceramic membranes for the filtration of fish press liquor, J. Membrane Sci. 384: 142-148 (2011).

25. Daufin G, Merin U, Labbe JP, Quemerais A and Kerhervé FH, Cleaning of inorganic membranes after whey and milk ultrafiltration. Biotechnol. Bioeng. 38: 82-89 (1991).

26. Guerrero L, Omil F, Méndez R and Lema JM, Protein recovery during the overall treatment of wastewaters from fish-meal factories, Bioresour. Technol. 63: 221-229 (1998).

27. Argüello MA, Álvarez S, Riera FA and Álvarez R, Enzymatic cleaning of inorganic ultrafiltration membrane used for whey protein fractionation. J. Membr. Sci. 216: 121-134 (2003).

28. Bartlett M, Bird MR, Howell JA, An experimental study for the development of a qualitative membrane cleaning model. J. Membr. Sci. 105: 147-157 (1995).

29. Cheryan M, Ultrafiltration and Microfiltration Handbook. Technomic Publishers, Lancaster (1998). 


\section{LIST OF TABLES AND FIGURES}

- Table 1. Intrinsic resistances, fouling resistances and cleaning efficiency indices for the cleaning protocol assayed.

- Figure 1. Process flowsheet.

- Figure 2. Pressure drop against volumetric flow of water (a) and press liquor (b) for the 465 micrometers (circles) and the $250 \mu \mathrm{m}$ metallic filter (squares).

- Figure 3. COD, content of suspended solids and the protein content of the press waters after each metallic filtration step.

- Figure 4. Time evolution of the permeate flux in the course of the concentration through the 200 $\mathrm{nm}$ ceramic membrane at temperature $20{ }^{\circ} \mathrm{C}$, transmembrane pressure 1.5 bar and cross-flow velocity $3.3 \mathrm{~m} / \mathrm{s}$.

- Figure 5. Time evolution of the protein content (squares) and the COD (circles) of the permeate stream obtained during the ultrafiltration through the $200 \mathrm{~nm}$ ceramic membrane at temperature $20^{\circ} \mathrm{C}$, transmembrane pressure 1.5 bar and cross-flow velocity $3.3 \mathrm{~m} / \mathrm{s}$.

- Figure 6. Water flux against transmembrane pressure for the fouled $200 \mathrm{~nm}$ membrane (circles), after alkaline cleaning (squares) and disinfection (triangles). Temperature was $20{ }^{\circ} \mathrm{C}$, transmembrane pressure 1.5 bar and cross-flow velocity $3.3 \mathrm{~m} / \mathrm{s}$. 


\begin{tabular}{lccc} 
After UF & $9.01 \cdot 10^{-3}$ & $7.49 \cdot 10^{-3}$ & - \\
$\mathrm{NaOH}$ & $2.79 \cdot 10^{-3}$ & $1.27 \cdot 10^{-3}$ & $83.04 \%$ \\
$\mathrm{NaOCl}$ & $1.53 \cdot 10^{-3}$ & $1.00 \cdot 10^{-5}$ & $16.82 \%$ \\
& - & - & $99.87 \%$ \\
\hline
\end{tabular}




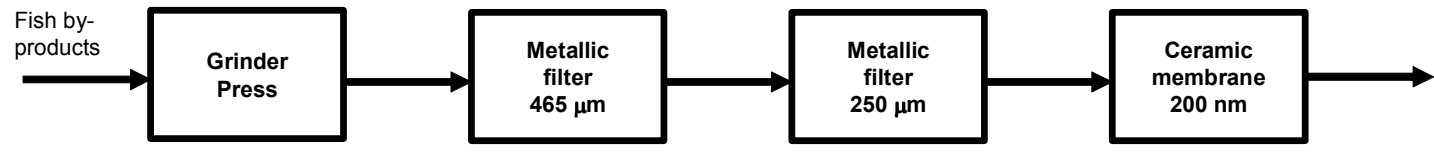

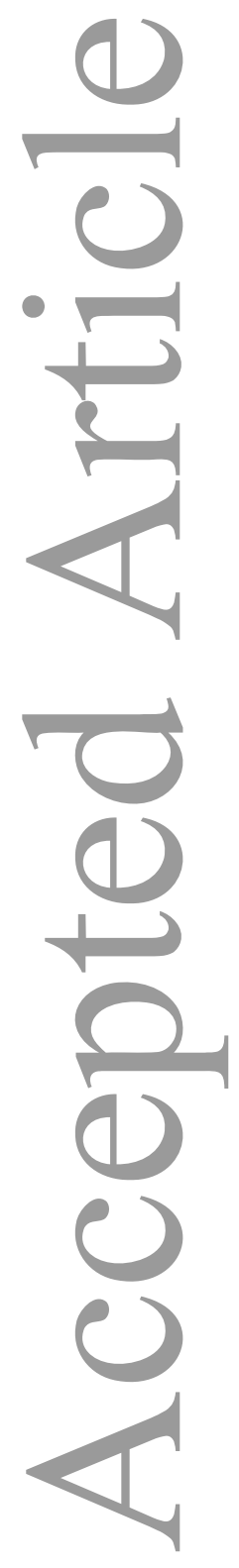


(a)
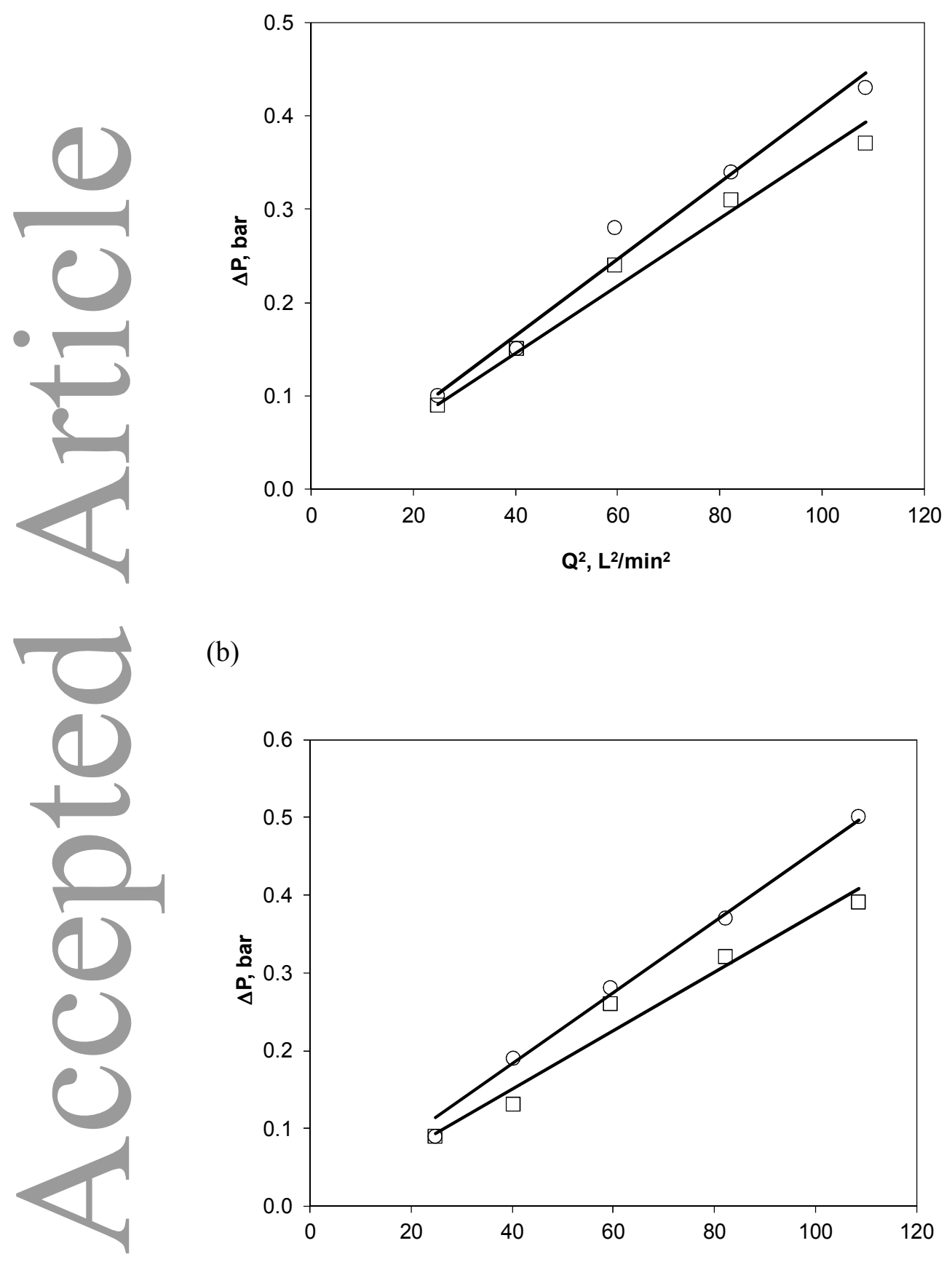

(b)

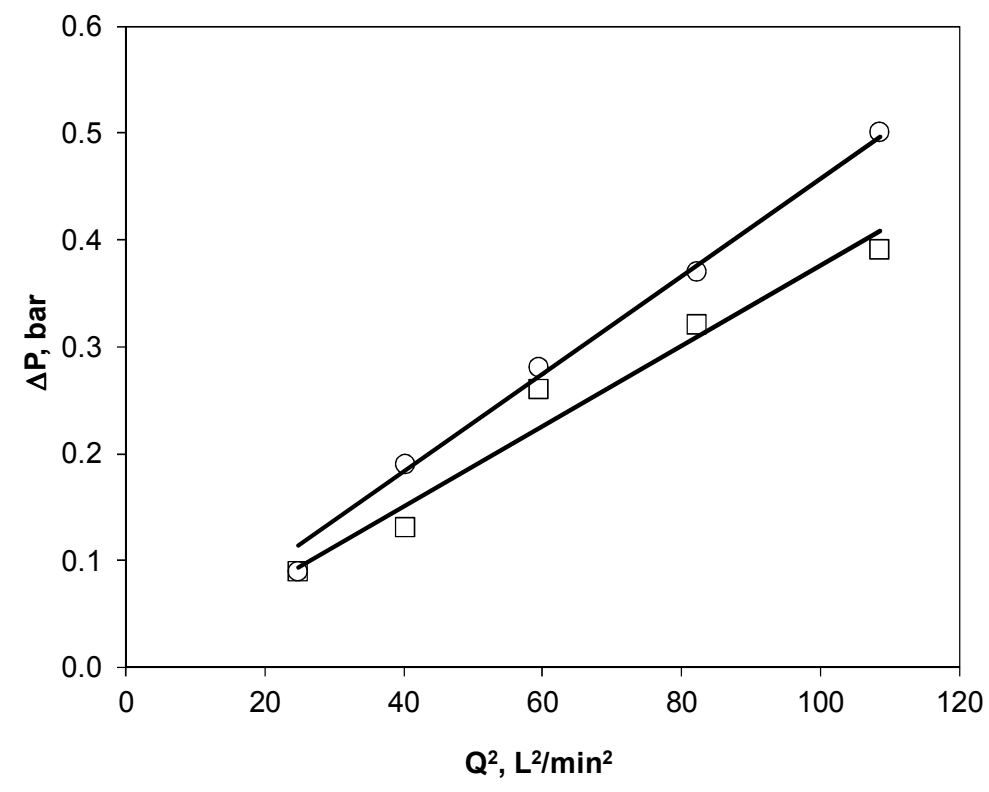




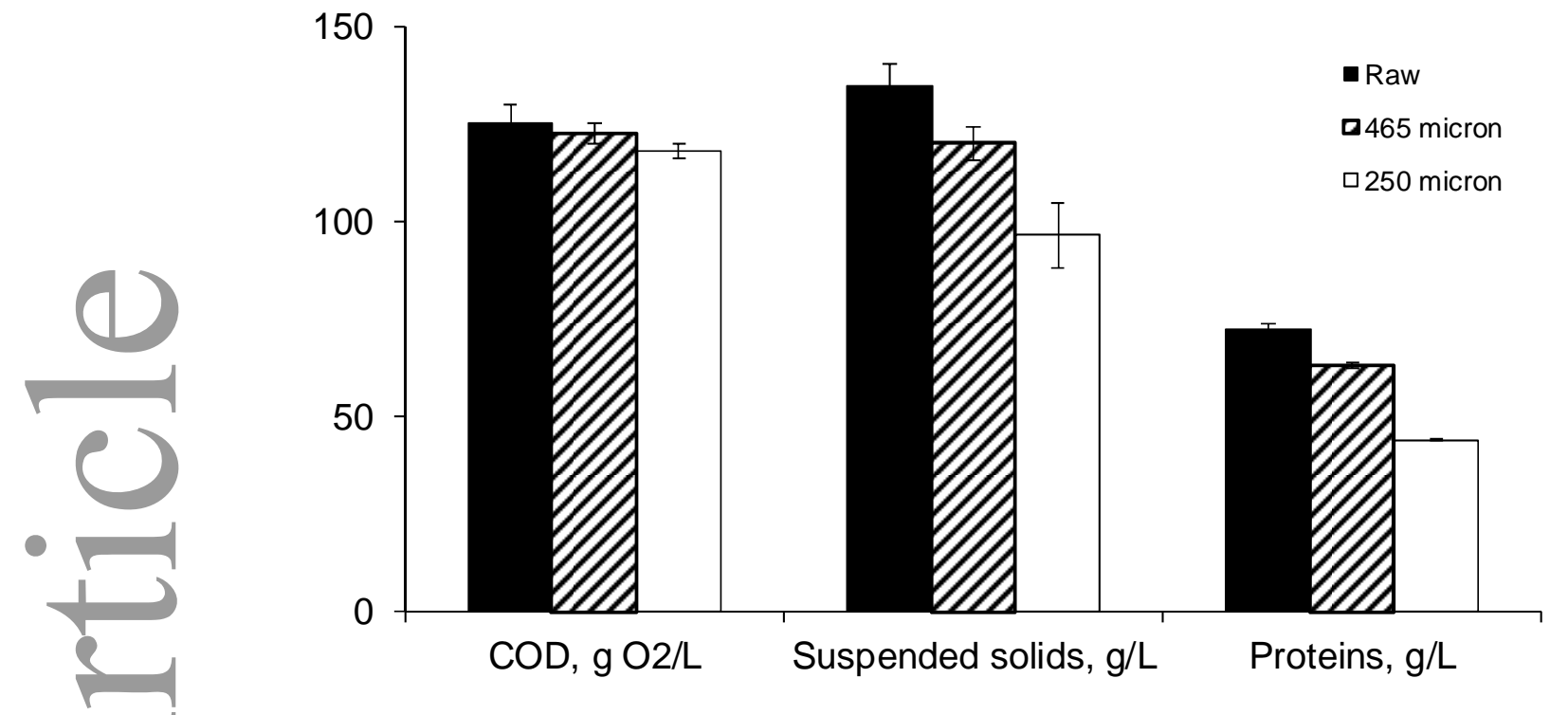



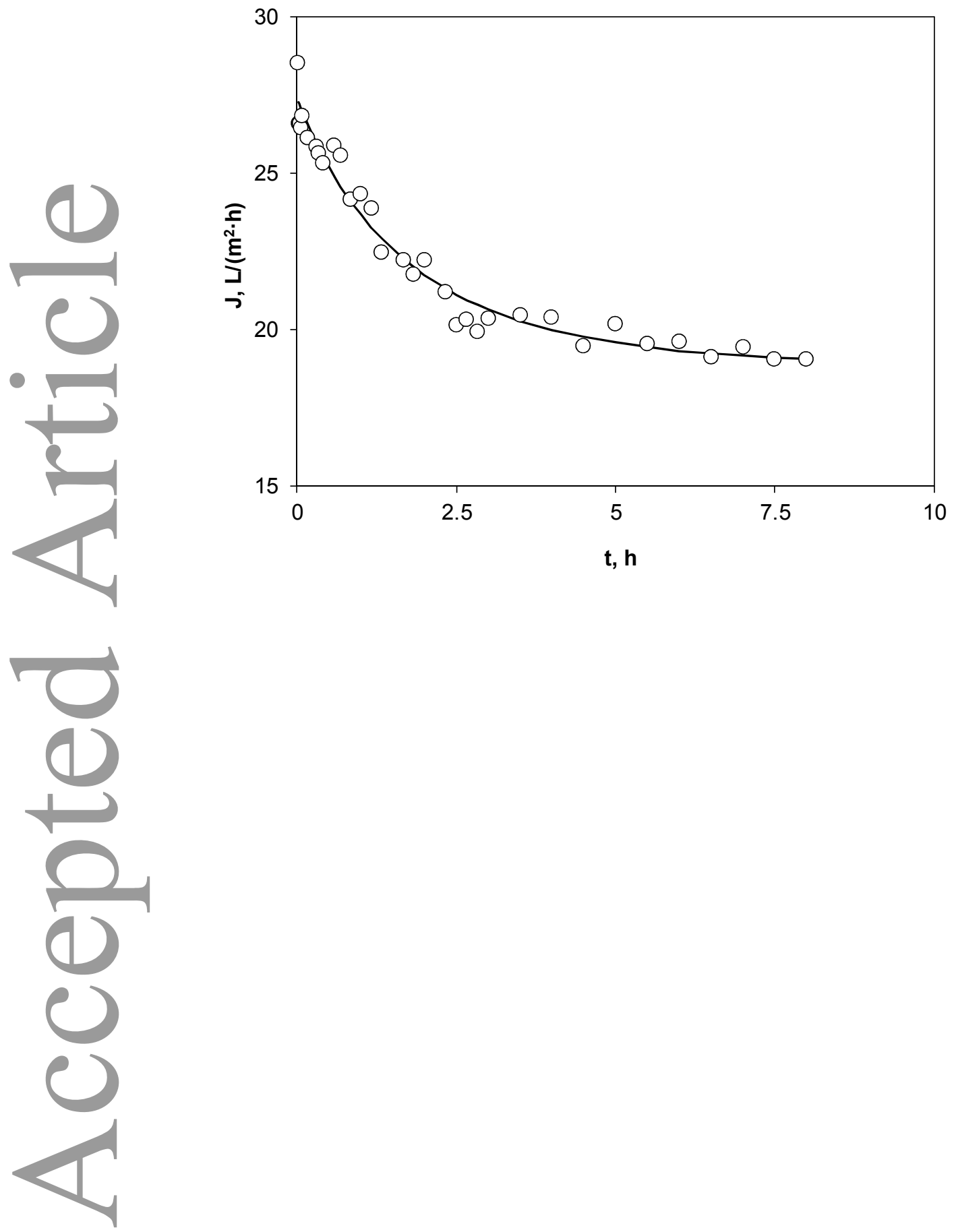


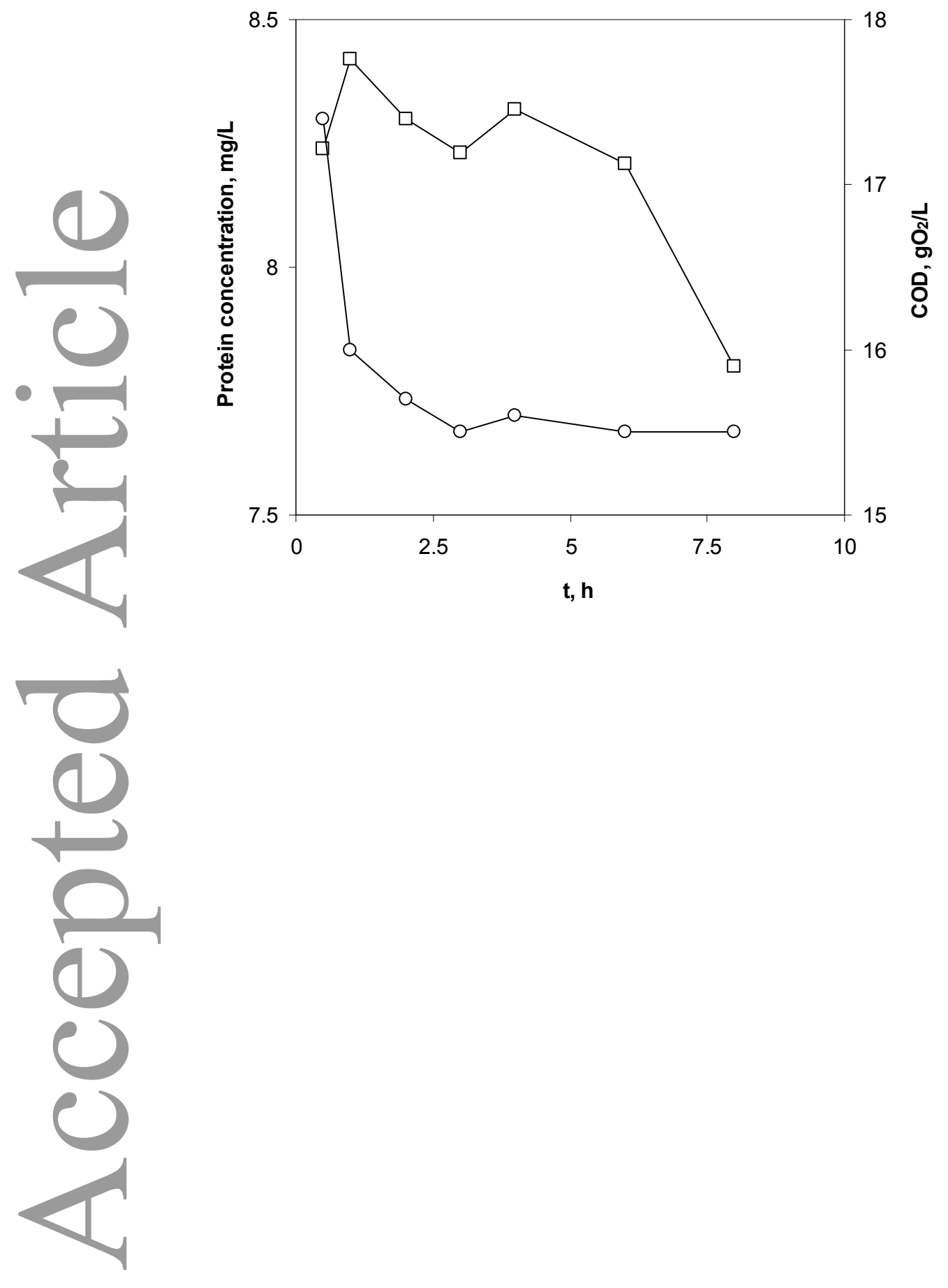




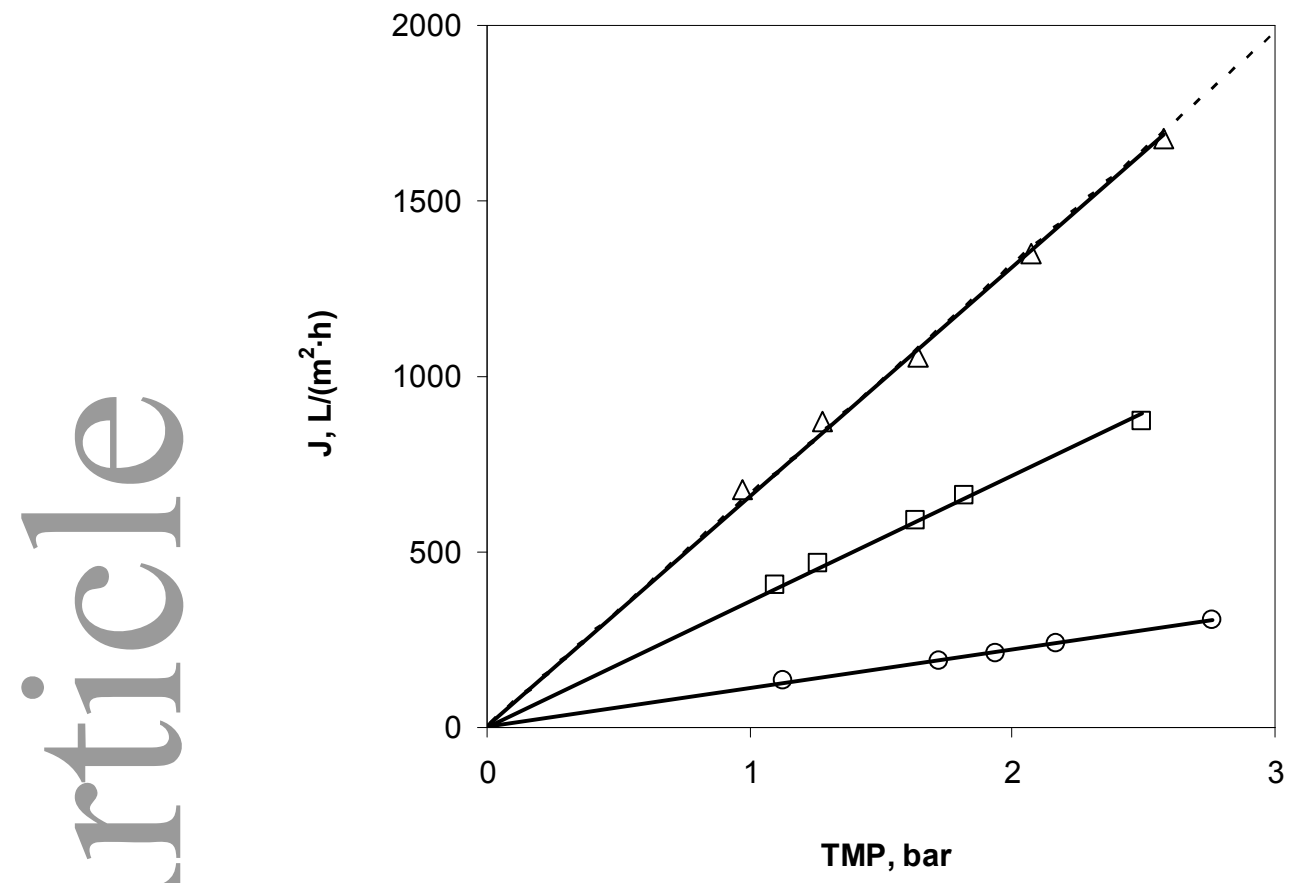

